\title{
Culture medium and inoculation methodology for the study of soft root rot caused by Phytopythium sp.
}

\section{Jonny Lucio de Sousa Silva ${ }^{1}$ (D) Alessandra Keiko Nakasone Ishida ${ }^{2}$ (D) Roberto Lisboa Cunha ${ }^{2}$ Aline Medeiros $\operatorname{Lima}^{1}$ Elisa Ferreira Moura ${ }^{2 *}$ iD}

${ }^{1}$ Programa de Pós-graduação em Agronomia, Universidade Federal Rural da Amazônia (UFRA), Belém, PA, Brasil. ${ }^{2}$ Embrapa Amazônia Oriental, 66095903, Belém, PA, Brasil. E-mail: elisa.moura@embrapa.br. "Corresponding author.

ABSTRACT: Cassava (Manihot esculenta Crantz) is an important crop in Brazil and Pará is the major producer of roots. High temperature and humidity of tropical regions favor the development of various diseases, among them the cassava root rot. The objective of this study was to evaluate the effect of luminosity and culture medium on the mycelial growth and sporulation of Phytopythium sp. associated with different methods of inoculation on cassava roots. In vitro tests for pathogen growth were established in a $2 x 6$ factorial design (luminosity $x$ culture medium) with five replicates and the means were compared by t test $(P \leq 0.05)$. The culture medium containing sweet cassava root produced greater mycelial development and higher pathogen sporulation and it was the most suitable medium for pathogen culture. The culture under absence of light generated better mycelial growth than culture under 12 hour of light. Regarding the type of inoculation, the response was better when deeper injuries were induced.

Key words: oomycete, sporulation, mycelium.

Meio de cultura e metodologia de inoculação para o estudo da podridão mole de raízes causada por Phytopythium sp.

RESUMO: A mandioca (Manihot esculenta Crantz) é uma importante cultura para o Brasil, onde o Pará é o principal produtor de raízes. Regiões tropicais com alta umidade e temperatura favorecem o desenvolvimento de diversas doenças, como as podridões de raiz. O presente estudo tem como objetivo avaliar o efeito da luminosidade e de meios de cultura no crescimento micelial e na esporulação de Phytopythium sp. e analisar métodos de inoculação do patógeno em raizes de mandioca destacadas. Os ensaios in vitro foram instalados em esquema fatorial $2 x 6$ (luminosidade $x$ meio de cultura), com cinco repetições e as médias comparadas pelo teste $t$ ( $p \leq 0,05)$. $O$ meio de cultura contendo raiz de mandioca mansa proporcionou maior desenvolvimento micelial e maior esporulação do patógeno e é o mais adequado para o cultivo do patógeno. O cultivo sob ausência de luz gerou melhor crescimento micelial do que o cultivo sob 12 horas de luz. Quanto ao tipo de inoculação, a resposta foi melhor nas raizes que obtiveram ferimentos mais profundos.

Palavras-chave: meio de cultura, oomiceto, esporulação, micélio.

\section{INTRODUCTION}

The state of Pará is the Brazil leading grower of cassava, producing 5.01 million tons from 501 thousand hectares in 2016 (CONAB, 2017). Root rot caused by various phytopathogens in the soil is among the main disease problems of this crop in the tropics. This class of disease is characterized by root necrosis, which begins with isolated dead spots and affects the entire root system. The principal pathogens responsible for causing root rot in cassava belong to the genera Fusarium and Phytophthora (OKECHUKWU et al., 2009). In the state of Pará, Phytopythium sp. have been recently reported as causing soft root rot in cassava (BOARI et al., 2018).

Recently, variousmethods of rootinoculation (VILAS BOAS et al., 2016) with oomycetes have been described for application in studies searching for new sources of resistance in cassava, such as inoculation of detached roots. However, methodologies to grown the oomycetes are still scarce.

The essential factors for a successful culture method include the composition and concentration of nutrients in the culture medium, the physiological variability of the isolate and 
environmental conditions such as temperature and luminosity, which can influence the development and sporulation of phytopathogens (CRUZ et al., 2009).

Due to the importance of the disease for cassava and the lack of studies about the genus Phytopythium associated with cassava root rot, the aim of this study was to evaluate the effect of luminosity and type of culture medium on the mycelial growth and sporulation of Phytopythium sp. and to analyze methods to inoculate the pathogen on detached cassava roots.

\section{MATERIALS AND METHODS}

The isolate CT 0084 of Phytopythium sp. was obtained from the mycology collection of Embrapa Amazônia Oriental in Belém, Pará, and was used in all the tests. The isolate was preserved according to the method of Castellani, considered the most suitable for oomycetes (CLARK \& DICK, 1974). For the experiment, the isolate was plated on PDA medium (200 g potato, $20 \mathrm{~g}$ agar and 20 $\mathrm{g}$ dextrose per liter of autoclaved distilled water). Seven days after incubation in the dark, the pathogen was transferred to plates containing sweet cassava dextrose agar (SCDA) and kept at $25{ }^{\circ} \mathrm{C} \pm 2{ }^{\circ} \mathrm{C}$ for 7 days. Then, the pathogenicity was tested by inoculation on detached cassava roots following the method proposed by CIAT (1990) and ONYEKA et al. (2005) for subsequent use in the experiments.

To optimize the sporulation and measure the mycelial growth of Phytopythium sp., six types of culture medium were tested: (i) V8 juice (V8 Juice, Campbell's) with $\mathrm{CaCO}_{3}$ (V8CC: $200 \mathrm{ml}$ of V8 juice, $1000 \mathrm{ml}$ of water, $3 \mathrm{~g}$ of $\mathrm{CaCO}_{3}$ ) adapted from ROMERO \& GALLEGLY, (1963); (ii) V8agar, leaving out the $\mathrm{CaCO}_{3}$, (iii) potato dextrose agar (PDA: $200 \mathrm{~g}$ of potato, $20 \mathrm{~g}$ of agar and $20 \mathrm{~g}$ of dextrose per liter of autoclaved distilled water); (iv) carrot dextrose agar (CDA: $20 \mathrm{~g}$ carrot root, $20 \mathrm{~g}$ dextrose and $20 \mathrm{~g}$ agar per liter of water); (v) bitter cassava dextrose agar (BCDA), adapted from the PDA medium with replacement of potato by bitter cassava; and (vi) sweet cassava dextrose agar (SCDA), also adapted from PDA, but with sweet cassava instead of potato. Besides the culture medium types, two light conditions were tested (12 $\mathrm{h}$ of artificial light and continuous darkness), both in a BOD (Biochemical Oxygen Demand) chamber with average temperature of $25^{\circ} \mathrm{C}$.

The culture media were placed in glass Petri dishes and after solidification, mycelium disks of the pathogen (diameter of $6 \mathrm{~mm}$ ) were placed in the center of each dish (the basic method both for mycelial growth and sporulation). The mycelial growth was evaluated daily by measuring the diameter of the colony with a digital pachymeter, until the pathogen covered the entire diameter of the dish.

For sporulation, the evaluation was performed 30 days after plating the pathogen. To obtain the suspension of sporangia, $5 \mathrm{~mL}$ of sterilized distilled water was added to each dish, and then, a Drigalski loop was used to scrape the colonies. Sporangia concentration was determined with a hemocytometer (Neubauer chamber), under an optical microscope and expressed as number of sporangia $/ \mathrm{ml}$.

The experiment was completely randomized in a $2 \times 6$ factorial design (two luminosity treatments and six culture media), with five replicates, each represented by a Petri dish with diameter of $90 \mathrm{~mm}$ and mycelial growth and sporulation were evaluated as variables. Data was evaluated to analysis of variance and media were submitted to t-test with $5 \%$ probability.

There were evaluated two cassava genotypes: CPATU 530 and BRS Poti, both maintained in the cassava active germplasm bank (AGB) of Embrapa Amazônia Oriental, located in Belém, Pará, Brazil. Two genotypes were planted in an area free of the disease. The place has humid tropical climate, with average yearly temperature of $27{ }^{\circ} \mathrm{C}$ and average annual rainfall of 2,500 $\mathrm{mm}$ (INMET, 2017), classified as AF2 according to Koppen. The plants were cultivated in full sunlight, with spacing of $1.0 \times 1.0 \mathrm{~m}$ in rows of 10 plants per genotype. The management of the crop followed the recommendations for growing cassava (MATTOS \& CARDOSO, 2003).

The protocol of inoculation was conducted in a growth chamber with controlled moisture (80\%) and temperature $\left(23{ }^{\circ} \mathrm{C}\right)$. Three types of procedures were tested: (1) without injury; (2) with superficial injury of the root, involving removal of the suber (suberized portion of the periderm of the root); and (3) with deep injury, reaching the root pulp.

Disks containing mycelia with diameter of $5 \mathrm{~mm}$ were removed from the SCDA culture medium for inoculation on detached roots (CIAT, 1990). For all the materials, three disks were inoculated on detached roots of 12 month-old plants, where the control was the inoculation with disks only containing SCDA medium.

Root samples were previously sterilized with $0.01 \%$ sodium hypochlorite and then each root was injured when necessary with a flame sterilized 
puncher with diameter of $5 \mathrm{~mm}$, with $4 \mathrm{~mm}$ of depth on average. After inoculation, the injured area was covered with plastic paraffin wax to maintain moisture and the roots were placed in a small chamber. Roots were watered twice a day with autoclaved distilled water until the end of the incubation period of each experiment. At the end of each inoculation experiment, roots were cut transversally with a knife at a $90^{\circ}$ angle to the axis of the root, to observe the evolution of the disease inside the root (ONYEKA et al., 2005).

\section{RESULTS AND DISCUSSION}

Considering the effect of the luminosity on the mycelial growth of Phytopythium sp., the pathogen grew significantly faster in the dark on all the culture media tested (Table 1), occupying the entire Petri dish surface by the third day after plating. The mycelial growth of the pathogen reached the plate's borders with $48 \mathrm{~h}$ on mediums SCDA, V8 and BCDA. BENNETT et al. (2017) also observed fast mycelial growth (less than three days) of Phytopythium genera, on culture medium containing cassava, under dark. For the mycelial growth, there was a $36 \%$ increase on SCDA medium under dark and $37 \%$ increase under $12 \mathrm{~h}$ light, when comparing with V8 medium (Table 1).

The SCDA medium showed the greatest production of sporangia and produced an average of $6.92 \times 10^{5}$ sporangia/ml under total darkness (Table 1), after 30 days. For the sporulation, there was a $441 \%$ increase on SCDA medium in the dark when comparing with V8 medium. Under $12 \mathrm{~h}$ light, the increase was $126 \%$.

According to NOZAKI et al. (2004), certain culture media are favorable to the sporulation of fungi because they present complex carbohydrates and are less suitable for the production of vegetative hyphae. In this study, the media containing bitter and sweet cassava in their formulation provided greater mycelial growth and greater sporulation. For oomycetes, reducing nutrient supply favors sporulation. According to MENDOZA \& PRENDAS (1988), the presence of certain ions, such as $\mathrm{Ca}^{2+}, \mathrm{Mg}^{2+}$ and $\mathrm{K}^{+}$in the culture medium, the $\mathrm{pH}$, the age of strains, agitation to provide $\mathrm{O}_{2}$ and temperature have also been pointed as important factors for sporulation. The authors verified a greater number of sporangia in medium with lack of nutrients ( $2 \%$ of water agar).

BENNETT et al. (2018) verified differences in mycelial growth and sporulation of two species of Phytopythium in culture media, relating such growths to three factors: luminosity, saline solution and soil extract solution. Quality and intensity of light are abiotic factors that can affect conidial germination, vegetative growth rate, induction of formation of reproductive structures, pigmentation, shape and size of spores of most fungal species, according to MATHUR \& NEERGAARD (1973).

After inoculation of roots without injury, no necrosis was observed in either of the two genotypes and in any repetition. However, for inoculation in deep injuries after removing all the barriers until

Table 1 - Mycelial growth index, measured in milimeters, and sporulation, measured in $10^{5}$ sporangia/ml of Phytopythium sp., causal agent of soft root rot in cassava (Manihot esculenta Crantz) in six culture media and two luminosity regimes.

\begin{tabular}{|c|c|c|c|c|c|c|c|c|c|c|c|c|c|c|c|c|}
\hline \multirow[b]{3}{*}{$\mathrm{SCDA}^{*}$} & \multirow{2}{*}{\multicolumn{2}{|c|}{---12h light--- }} & \multirow{2}{*}{\multicolumn{2}{|c|}{ Total darkness }} & \multicolumn{6}{|c|}{ 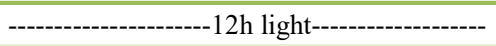 } & \multicolumn{6}{|c|}{------------------Total darkness---------------- } \\
\hline & & & & & \multirow{2}{*}{$\begin{array}{c}24 \mathrm{~h} \\
47.2\end{array}$} & & \multicolumn{2}{|c|}{$48 \mathrm{~h}$} & \multicolumn{2}{|l|}{$72 \mathrm{~h}$} & \multicolumn{2}{|c|}{$24 \mathrm{~h}$} & \multicolumn{2}{|c|}{$48 \mathrm{~h}$} & \multicolumn{2}{|c|}{$72 \mathrm{~h}$} \\
\hline & 5.46 & $\mathrm{aA}$ & 6.92 & $\mathrm{aA}$ & & $\mathrm{bC}$ & 90 & $\mathrm{aB}$ & 90 & $\mathrm{aA}$ & 48.9 & $\mathrm{aC}$ & 90 & $\mathrm{aB}$ & 90 & $\mathrm{aA}$ \\
\hline $\mathrm{CDA}$ & 0.94 & $\mathrm{dA}$ & 1.91 & $\operatorname{cdA}$ & 39.9 & $\mathrm{cC}$ & 75.3 & $\mathrm{bB}$ & 90 & $\mathrm{aA}$ & 42.6 & $\mathrm{cC}$ & 78.8 & $\mathrm{bB}$ & 90 & $\mathrm{aA}$ \\
\hline PDA & 3.1 & $\mathrm{bcA}$ & 2.73 & $\mathrm{cA}$ & 38.8 & $\mathrm{cC}$ & 74 & $\mathrm{bB}$ & 90 & $\mathrm{aA}$ & 41.1 & $\mathrm{dC}$ & 74.7 & $\mathrm{cB}$ & 90 & $\mathrm{aA}$ \\
\hline V8CC & 3.16 & $\mathrm{bcA}$ & 2.25 & $\operatorname{cdA}$ & 39.9 & $\mathrm{cC}$ & 75.6 & $\mathrm{bB}$ & 90 & $\mathrm{aA}$ & 42.4 & $\mathrm{cC}$ & 78 & $\mathrm{bB}$ & 90 & $\mathrm{aA}$ \\
\hline V8 & 2.42 & $\mathrm{cA}$ & 1.28 & $\mathrm{dA}$ & 34.7 & $\mathrm{cC}$ & 61.5 & $\mathrm{cB}$ & 90 & $\mathrm{aA}$ & 35.8 & $\mathrm{eC}$ & 90 & $\mathrm{aB}$ & 90 & $\mathrm{aA}$ \\
\hline BCDA & 4.05 & $\mathrm{bA}$ & 4.86 & $\mathrm{bA}$ & 54.9 & $\mathrm{aC}$ & 90 & $\mathrm{aB}$ & 90 & $\mathrm{aA}$ & 47.9 & $\mathrm{bC}$ & 90 & $\mathrm{aB}$ & 90 & $\mathrm{aA}$ \\
\hline
\end{tabular}

The lower-case letters indicate significant differences in the mycelial growth index among the culture media and the upper-case leters indicate differences between luminosity regimes, as indicated by t-test at 5\%. Mycelial growth index was measured and expressed in millimeters (mm).

${ }^{*}$ Sweet cassava dextrose agar (SCDA), carrot dextrose agar (CDA), potato dextrose agar (PDA), V8-agar (V8), V8 juice with CaCO 3 (V8CC) and bitter cassava dextrose agar (BCDA) 
reaching the root pulp, necrosis was observed in all the genotypes seven days after inoculation, as well as VILAS BOAS et al. (2016) without any distinction regarding severity.

When keeping the roots in a growth chamber with controlled temperature $\left(25^{\circ} \mathrm{C}\right.$ and humidity $80 \%$ ), for approximately seven days, the best inoculation method was to use deeper wounds (4mm depth on average). SIVIERO et al. (2002), evaluating methods of inoculation of Phytophthora parasitica in Citrus seedlings, verified that the plants inoculated by the method of contact between plants without injury and pathogen did not present lesions, being able to verify that the pathogen needs injury to penetrate the plant and cause disease.

Thus, the best culture media both for mycelial growth and sporulation of Phytopythyum sp. is SCDA and BCDA and culture under darkness can improve mycelial growth.

\section{ACKNOWLEDGEMENTS}

The authors thank the Conselho Nacional de Desenvolvimento Científico e Tecnológico $(\mathrm{CNPq})$, process No. 408042/2013-3, the Coordenação de Aperfeiçoamento de Pessoal de Nivel Superior (CAPES) for the scholarship grant of the first author and the Empresa Brasileira de Pesquisa Agropecuária (Embrapa) for financial and structural support.

\section{DECLARATION OF CONFLICT OF} INTERESTS

The authors declare no conflict of interest. The founding sponsors had no role in the design of the study; in the collection, analyses, or interpretation of data; in the writing of the manuscript, and in the decision to publish the results.

\section{AUTHORS' CONTRIBUTIONS}

All authors contributed equally for the conception and writing of the manuscript. All authors critically revised the manuscript and approved of the final version.

\section{REFERENCES}

BENNETT, R.M.; BORA, N.; DEDELES, G.R.; THINES, M. Phytopythium leanoi sp. nov. and Phytopythium dogmae sp. nov., Phytopythium species associated with mangrove leaf litter from the Philippines. Acta Mycologica, v.52, n.2, 1103, 2017. Available from: <https://pbsociety.org.pl/journals/index.php/am/article/view/ am.1103/7417>. Accessed: Sep. 9, 2018. doi: 10.5586/am.1103.

BOARI, A.J.; CUNHA, E.M.; QUADROS, A.F.F.; BARRETO, R.W. \& FERNANDES, A.F. First report of Phytopythium sp. causing storage root rot and foliage blight of cassava in Brazil. Plant Disease, v.102, p.1042, 2018. Available from: <https:// apsjournals.apsnet.org/doi/full/10.1094/PDIS-09-17-1449-PDN>. Accessed: Jun. 06, 2018. doi: 10.1094/PDIS-09-17-1449-PDN.
CIAT. CIAT Annual Report: Cassava Program. Cali, Colombia: International Center for Tropical Agriculture (CIAT), 387p. 1990. Available from: <https://cgspace.cgiar.org/handle/10568/67431>. Accessed: Jun. 06, 2018.

CLARK, G. \& DICK, M.W. Long-term storage and viability of aquatic Oomycetes. Transactions of the Bryological Society. London, v.63, p.611-612, 1974.

Companhia Nacional de Abastecimento (CONAB). Conjuntura das agropecuárias, 2017. Available from: <http://www.conab. gov.br>. Accessed: May, 31, 2018.

CRUZ, M.F.A.; PRESTES, A.M. \& MACIEL, J.L.N. Esporulação de Pyricularia grisea em diferentes meios de cultura e regimes de luz. Ciência Rural, v.39, p.1562-1564, 2009. Available from: $<$ http://www.redalyc.org/articulo.oa?id=33113643040 $>$. Accessed: Jun. 06, 2018. doi: 10.1590/S0103-84782009000500040.

Instituto Nacional de Metereologia (INMET) Dados de estações automaticas, 2017. Available from: < http://sisdagro.inmet.gov.br/ sisdagro/app/monitoramento/bhs $>$. Accessed: May, 11, 2017.

MATHUR, S.B. \& NEERGAARD, P. Seed health testing of rice IV. Effect of light and temperature on seed-borne fungi in the blotter test. Handbook on Seed Health Testing, Vollebekk, v.37, n.3, p.723-730, 1973.

MATTOS, P.L.P. \& CARDOSO, E.M.R. Cultivo da mandioca para o estado do Pará. Available from: <http://sistemasdeproducao. cnptia.embrapa.br>. Accessed: Mar. 31, 2019.

MENDOZA, L. \& PRENDAS, J. A method to obtain rapid zoozporogenesis of Pythium insidiosum. Mycopathologia, v.104, p.59-62, 1988. Available from: <https://ink.springer.com/ article/10.1007/BF00437925>. Accessed: Sep. 9, 2019. doi: 10.1007/BF00437925.

NOZAKI, M.H.; CAMARGO, M.E. \& BARRETO, M. Caracterização de Diaporthe citri em diferentes meios de cultura, condições de temperatura e luminosidade. Fitopatologia brasileira, v.29, p.429-432, 2004. Available from: <http:// www.scielo.br/scielo.php? script $=$ sci_arttext\&pid $=$ S0100$41582004000400012 \& \operatorname{lng}=$ en $\& n r m=$ iso $\&$ tlng $=p t>$. Accessed: Sep. 9, 2019. doi: 10.1590/S0100-41582004000400012.

OLIVEIRA, A.S.S. DE; HOHENFELD, C.S.; SANTOS, V. DA S.; HADDAD, F. \& OLIVEIRA, E.J. Resistance to Fusarium dry root rot disease in cassava accessions. Pesquisa Agropecuária Brasileira, v.48, p.1414-1417, 2013. Available from: <http://www. scielo.br/scielo.php?pid=S0100-04X2013001000014\&script $=$ sci_ arttext\&tlng=es>. Accessed: Jun. 06, 2018. doi: 10.1590/S0100204X2013001000014

ONYEKA, T.J., DIXON, A.G.O. \& EKPO E.J.A. Assessment of laboratory methods for evaluating cassava genotypes for resistance to root rot disease. Mycopathologia, v.159, p.461-467, 2005. Available from: $<\mathrm{https}: / /$ link.springer.com/content/pdf/10.1007\%2Fs11046-0046156-Z.pdf $>$. Accessed: Jul. 06, 2018. doi: 10.1007/s11046-004-6156-Z.

OKECHUKWU, R.U.; DIXON, A.G.O.; AKORODA, M.O.; MWANGI, M. \& BANDYOPADHYAR, R.R. Root rot resistance in new cassava varieties introduced to farmers in Nigeria. Experimental Agriculture, v.45, p.15-24, 2009. Available from: $<$ https://www. cambridge.org/core/journals/experimental-agriculture/article/rootrot-resistance-in-new-cassava-varieties-introduced-to-farmers-in 
nigeria/FEB730C9311F5DB87B71F004 DE1A428B $>$. Accessed: Jul. 06, 2018. doi: 10.1017/S0014479708006777.

ROMERO, S. \& GALLEGLY, M.E. Oogonium germination in Phytophthora infestans. Phytopathology, v.53, p.899-903, 1963.

SIVIERO, A.; FURTADO, E.L.; BOAVA, L.P.; BARBASSO, D.V. e MACHADO, M.A. avaliação de métodos de inoculação de Phytophthora parasitica em plântulas e plantas jovens de citros. Fitopatologia brasileira, v.26, p.574-580, 2002. Available from:
$<$ http://www.scielo.br/scielo.php?script=sci_arttext\&pid=S0100$41582002000600003 \& \operatorname{lng}=$ en\&nrm $=$ iso\&tlng $=\mathrm{pt}>$. Accessed: Sep. 9, 2019. doi: 10.1590/S0100-41582002000600003.

VILAS BOAS, S.A.; HOHENFELD, C.S.; OLIVEIRA, S.A.S.; SANTOS, V.S. \& OLIVEIRA, E.J. Sources of resistance to cassava root rot caused by Fusarium spp.: a genotypic approach. Euphytica, v.209, p.237-251, 2016. Available from: <https://link.springer.com/ article/10.1007/s10681-016-1676-4>. Accessed: Sep. 9, 2019. doi: 10.1007/s10681-016-1676-4. 